\title{
Ber-MAC3: new monoclonal antibody that defines human monocyte/macrophage differentiation antigen
}

\author{
E Backé, R Schwarting, J Gerdes, M Ernst, H Stein
}

\begin{abstract}
A new monoclonal antibody Ber-MAC3 is reported. It recognises a formol sensitive epitope of a not yet clustered monocyte/macrophage specific 140 kilodalton glycoprotein that is expressed on the cell surface and in the cytoplasm. In 30 cases of acute and chronic leukaemia, Ber-MAC3 staining was restricted to 15 myeloid leukaemias of M4 and M5 types. The tumour cells of two cases of true histiocytic malignancies were Ber-MAC3 positive, whereas those of all 280 malignancies of lymphocytic origin were negative. The latter included 52 cases of Hodgkin's disease and 41 cases of $\mathrm{Ki}-1$ positive anaplastic large cell lymphomas which had previously been classified as true histiocytic lymphomas.

Ber-MAC3 therefore seems to be of considerable value for selective identification of monocytes and macrophages at a certain stage of differentiation and seems to be suitable for diagnosing myelomonocytic or monocytic leukaemia and neoplasms of true histiocytic origin.
\end{abstract}

Considerable morphological and functional diversity is seen in cells of the mononuclear phagocyte system (MPS), which includes blood monocytes, resident macrophages of various tissues, starry sky macrophages (equivalent of tingible body histiocytes), and epithelioid type macrophages and multinucleated giant cell macrophages of Langhans', foreign body, or Touton type. Because of this great heterogeneity, a clear distinction between the different MPS cells and cells of other systems is often impossible, especially when they have undergone malignant transformation. Several monoclonal antibodies have been developed which recognise certain subsets of the MPS. ${ }^{1-25}$ But a correlation between the various functions of these cellsfor example, antigen presentation, cytotoxic activity, secretion of factors regulating cellular functions, secretion of enzymes and oxygen free radicals-and different stages of differentiation by defining subpopulations is not yet possible as it is for $B$ and $T$ cells.

A new monoclonal antibody, Ber-MAC3, defines a distinct stage of differentiation/activation of monocytes/macrophages. Ber-MAC3 is unreactive with normal and neoplastic cells of non-myeloid lineages, and, in myeloid leukaemia, its reactivity is restricted to the M4/M5 type.

\section{Methods}

Suspended mononuclear splenocytes $\left(1 \times 10^{7}\right)$ containing monocytes, macrophages, and $\mathbf{B}$ cells, were used for a weekly immunisation of $\mathrm{balb} / \mathrm{c}$ mice over a period of six weeks. The spleen was obtained fresh from a normal donor after a traumatic rupture.

Somatic cell hybridisation was performed three days after the last immunisation according to the protocol of $\mathrm{Oi}$ and Herzenberg. ${ }^{26}$ Supernatants from wells exhibiting hybrid growth were tested by immunoenzymatic staining with the alkaline phosphatase antialkaline phosphatase (APAAP) method $^{27}$ on frozen sections of human tonsil and lymph node from a patient with Hodgkin's disease.

The immunoglobulin subclass of the monoclonal antibody was determined by double immunodiffusion using subclass specific rabbit anti-mouse reagents (Serotec, Wiesbaden, Germany).

All cells were cultured in RPMI medium (Biochrom, Berlin, Germany) containing 10\% fetal calf serum (FCS) (Gibco, Berlin), $4 \mathrm{mM}$ glutamine $10 \mathrm{U} / \mathrm{ml}$ penicillin, and $0.1 \mathrm{mg} / \mathrm{ml}$ streptomycin (Boehringer, Mannheim, Germany). Peripheral blood lymphocytes were prepared from anticoagulated blood by FicollHypaque density centrifugation. $T$ cells were obtained by E-rosette formation using sheep red blood cells treated with 2-aminoethylisothiouronium-bromide-hydrobromide (AET). Monocytes were isolated from the non-rosetting cells by adherence to tissue culture Petri dishes. B cells were obtained by careful removal of non-adherent cells from the non Erosette forming cells taken from the tonsils of children after tonsillectomy. $T$ cells were stimulated in normal RPMI medium containing $1 \%(v / v)$ phytohaemagglutinin (PHA) or $10 \mu \mathrm{g} / \mathrm{ml}$ Concanavalin A (ConA) for three days. $B$ cells were stimulated in normal RPMI medium containing $2 \times 10^{-5}(\mathrm{v} / \mathrm{v})$ Staphylococcus aureus (Calbiochem, Giessen, Germany) cells $/ \mathrm{ml}$ medium and in medium containing $1 \%$ (v/v) Pokeweed mitogen. HL-60, U-937, and $\mathrm{THP}-\mathrm{1}^{28}$ cell lines were stimulated with 0-tetradecanyol phorbol diester (TPA) (Sigma, Munich, Germany) at a concentration of $100 \mathrm{ng} / \mathrm{ml}, 10 \mathrm{U} / \mathrm{ml}$, or $100 \mathrm{IU} / \mathrm{ml} \mathrm{IFN-G}$ (Amersham, Braunschweig, Germany) for three, seven, and 14 days. Monocytes were cultured for three days in normal medium or were stimulated either with $10 \mu \mathrm{g} / \mathrm{ml}$ 
lipopolysaccharide Escherichia coli B05:55 (Sigma) or $10 \mathrm{IU} / \mathrm{ml}$ IFN-G (Amersham), or monocytes were primed with 10 IU IFN-G/ml for two and a half hours, to which $10 \mathrm{ng} / \mathrm{ml}$ lipopolysaccharide were added. For giant cell formation, monocytes were cultured for 14 days in medium containing $10 \%$ human serum which was changed every third day. The effect of Ber-MAC3 on the formation of giant cells was investigated by incubating monocytes in medium containing Ber-MAC3 ascites ( 1 in 100,1 in 1000). Control experiments were performed in medium without immunoglobulin and in medium containing an irrelevant non-binding antibody $(\mathrm{Ki}-27){ }^{29}$

All normal, inflammatory and neoplastic tissues, and leukaemic cells orginated from the Department of Pathology or the Department of Haematology, Steglitz Medical Centre, Berlin, FRG. Normal tissues were chosen at random from three different subjects. All malignant non-Hodgkin's lymphomas (NHL) were classified according to the updated Kiel classification, using both morphological and immunophenotypical criteria. ${ }^{3031}$ The cases of Hodgkin's disease were subtyped according to the Rye classification. ${ }^{32}$ The myeloid leukaemias were typed according to the FrenchAmerican-British classification. The sections from all normal tissues were stained at least three times.

Control antibodies used for immunohistological staining and biochemical experiments were anti-CD1a NA1/34 (Dakopatts), epithelial cell specific Lu5 (Boehringer, Mannheim, Germany), FDC specific R4/23, ${ }^{33}$ anti-CD30 Ber-H2, ${ }^{34}$ anti-CD11c S-HCL3, ${ }^{1}$ monocyte/ macrophage specific $\mathrm{Ki}-\mathrm{M} 6,{ }^{22}$ and proliferation-associated $\mathrm{Ki}-67 . .^{35}$ As a negative control antibody, the non-binding variant (W6/32HK) of a class I monoclonal antibody was used.

\section{IMMUNOHISTOLOGY}

Biopsy specimens of human tissue were snapfrozen in liquid nitrogen and were stored at $-80^{\circ} \mathrm{C}$. Frozen sections of $8 \mu \mathrm{m}$ were prepared with a 2800 Frigocut-cryostat (Reichert-Jung, Heidelberg, Germany) and fixed for 30 minutes in acetone and 30 minutes in chloroform. The APAAP staining technique was performed as described by Cordell et al. ${ }^{27}$

\section{IMMUNOFLUORESCENCE}

The cells were fixed by resuspending the cells in $70 \%$ cold ethanol on ice for 20 minutes before incubation with the first antibody. To discriminate between cytoplasmic and surface labelling non-fixed cells were also used. Cells ( 1 $\times 10^{6}$ ) were incubated with $100 \mu$ l of monoclonal antibody at a saturated concentration at $4^{\circ} \mathrm{C}$ for 30 minutes. The cells were washed twice and subsequently incubated with fluorescence goat $\mathrm{F}(\mathrm{ab})_{2}$ anti-mouse IgG (Dakopatts), washed twice again, and then analysed on an EPICS 752 flow cytometer (Coulter, USA), equipped with a $5 \mathrm{WR}$-gun laser at an excitation wavelength of $488 \mathrm{~nm}$.

BIOCHEMICAL CHARACTERISATION OF THE TARGET ANTIGEN

Viable human alveolar macrophages were tritiated by the borohydride method ${ }^{36}$ and lysed with phosphate buffered saline (PBS) containing $1 \%$ Triton $\mathrm{X}-100$ and $2 \mathrm{mM}$ phenylmethyl-culfonylfluoride (PMSF) (Sigma). For internal labelling $6 \times 10^{7}$ cells of the DHL- $1^{37}$ cell line were washed three times with methionine-free medium (Gibco) without FCS, then suspended in medium without methionine, containing $10 \%$ FCS (dialysed against methionine-free RPMI 1640) at a concentration of $1 \times 10^{6} \mathrm{cells} / \mathrm{ml}$ and incubated for 30 minutes at $37^{\circ} \mathrm{C}$ and $5 \%$ carbondioxide. Then $1 \mathrm{mCi}$ ${ }^{35} \mathrm{~S}$-methionine (NEN-Dupont, Dreieich, Germany) was added and the cells were incubated for 20 hours. Cells were harvested, washed three times with medium containing methionine (Gibco), and the cell pellet was lysed in PBS containing $0.02 \% \mathrm{NaN}_{3}$ (Merck, Darmstadt, Germany), 1\% NP40 (LKB, Bromma, Sweden), and $1 \mathrm{mM}$ PMSF (Sigma) for 2 hours at $4^{\circ} \mathrm{C}$. The antigen was precipitated from the cell lysate as well as from cell culture supernatant. Immunoprecipitation was performed according to Schwarting et al. ${ }^{1}$ The molecular weight of the target antigen was determined by running the precipitates from alveolar macrophages on a $5 \%-20 \%$ polyacrylamide gradient gel and by running the DHL-1 cell precipitates on a $10 \%$ polyacrylamide gel.

\section{FUNCTIONAL ANALYSIS}

Investigation of the chemoluminescence response was performed using the modified method of Kato. ${ }^{38}$ Cells for detection of chemoluminescence were suspended in chemoluminescence medium (DMEM containing $50 \mathrm{mM}$ of HEPES, $\mathrm{pH} 7 \cdot 4$, without $\mathrm{NaHCO}_{3}$ and phenol red (Boehringer)). Luminol (Boehringer) was dissolved in PBS (2 $\mathrm{mg} / \mathrm{ml}$ ), supplemented with $8 \mu \mathrm{l}$ triethylamin/ $\mathrm{ml}$ (Kato). Zymosan particles (Sigma) were suspended at a concentration of $50 \mathrm{mg} / \mathrm{ml}$. Latex beads $(1 \cdot 1 \mu \mathrm{m}$ diameter) were adjusted to $6 \times 10^{9}$ particles $/ \mathrm{ml}$ chemoluminescence medium. A $0 \cdot 1 \mathrm{mM}$ solution of FMLP (Sigma) was used. Sheep erythrocytes optimally sensitised with rabbit IgG anti-E antibodies were obtained from Cordis, Miami, USA. The concentration of red cells was $10^{8} / \mathrm{ml}$. Chemoluminescence was measured in a sixchannel luminescence measuring device (LB 9505, Berthold, Wildbad, Germany) at $37^{\circ} \mathrm{C}$. Cell suspensions $(300 \mu \mathrm{l})$ were mixed with $10 \mu \mathrm{l}$ of luminol solution. Phagocytosis was started after two minutes of chemoluminescence background recording by adding $10 \mu \mathrm{l}$ of phagocytosis stimulus. The data continuously obtained were displayed and recorded on line (Apple II computer).

The chemoluminescence response was measured with untreated monocytes as control and with monocytes incubated with BerMAC3 ascites (diluted 1 in 100,1 in 200, and 1 in 500), Fab fragments, and purified immunoglobulin $(1-150 \mu \mathrm{g} / \mathrm{ml})$. Purified immunoglobulins were obtained by using the Bio-Rad Affi-Gel Protein A MAPS-II Kit (Bio-Rad, Richmond, California, USA).

For preparation of Fab fragments, purified immunoglobulins were diluted at a concentra- 


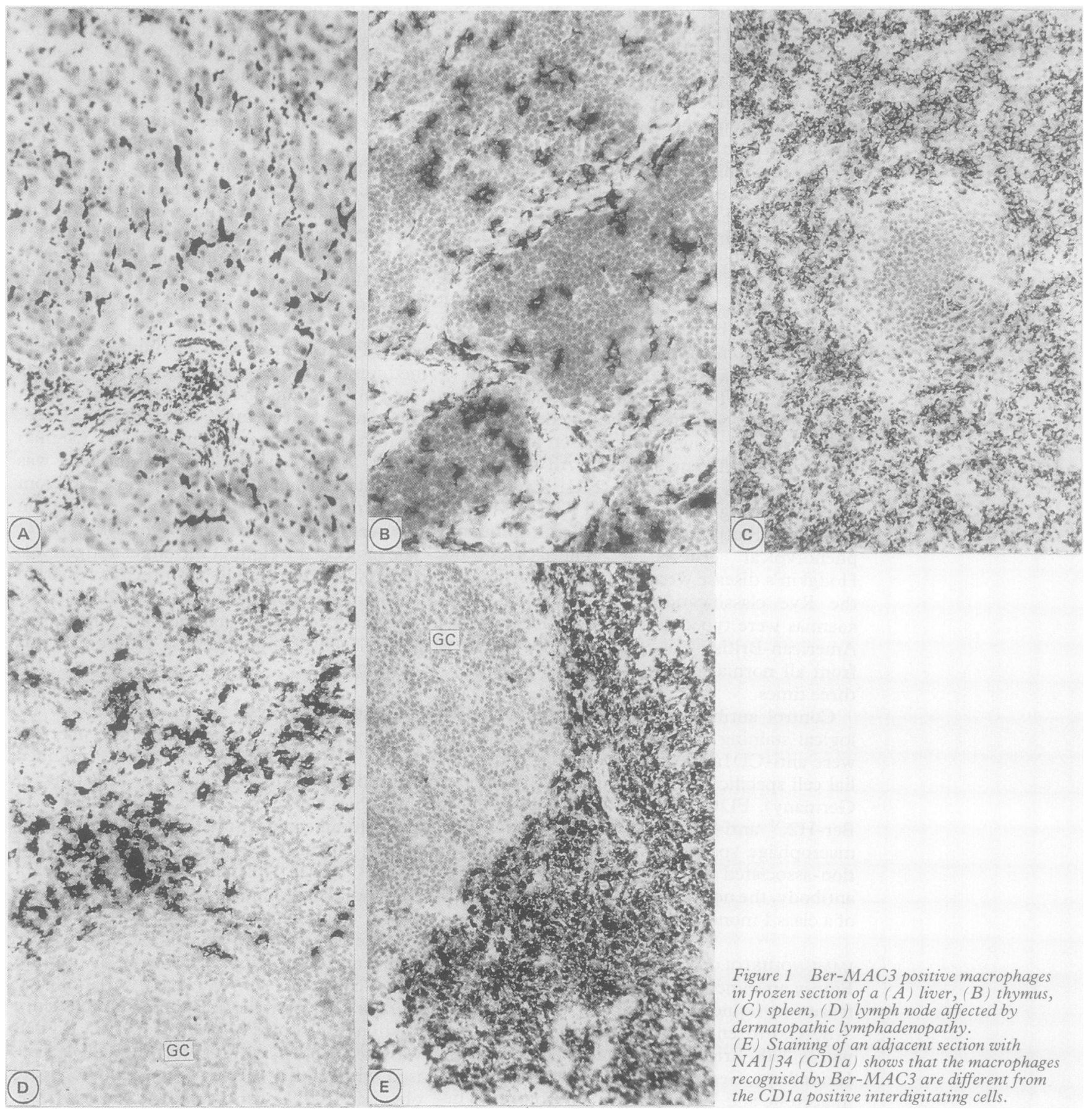

sodium phosphate, $5 \mathrm{mM}$ EDTA (pH 7.0), and digested with Papain (Sigma) for four hours at $37^{\circ} \mathrm{C}$. The ratio of enzyme to protein was $1: 100$. After Papain cleavage Fab fragments were separated from the Fc fragments by purification with the Bio-Rad Affi-Gels Protein A MAPSII Kit.

An irrelevant monoclonal antibody belonging to the same subclass - that is, $\mathrm{Ki}-67^{35}$ - was used as a control.

\section{Results}

PRODUCTION OF BER-MAC3

Screening of about 500 supernatants from hybridomas generated with a mixture of spleen cells containing monocytes, macrophages, and $B$ cells showed several antibodies with a macro- phage tissue binding pattern. The antibody with the most selective and strongest reactivity with tissue macrophages was selected for further characterisation. This antibody, designated Ber-MAC3, proved to be of IgG1 subclass and ineffective in routinely processed paraffin wax sections.

\section{IMMUNOHISTOLOGICAL REACTIVITY OF} BER-MAC3 IN NORMAL AND DISEASED TISSUE Immunostaining of frozen sections from a large range of normal human tissues with Ber-MAC3 showed that it reacted strongly with most or all macrophages in all tissues investigated (tables 1 and 2; figs $1 \mathrm{~A}-\mathrm{C}$ ) with the following exceptions: most starry sky macrophages of lymphoid follicles (fig 2G); all epithelioid type macrophages, and all multi- 
Table 1 Reactivity of Ber-MAC3 in normal tissues determined by APAAP immunostaining of frozen sections

\begin{tabular}{|c|c|}
\hline Type of tissue/cells & Ber-MAC3 reactivity \\
\hline $\begin{array}{l}\text { Spleen: } \\
\text { Macrophages of the red pulp } \\
\text { Macrophages of the white pulp } \\
\text { Sinus lining cells } \\
\text { B and T cells }\end{array}$ & $\begin{array}{l}+ \\
+ \\
- \\
-\end{array}$ \\
\hline $\begin{array}{l}\text { Lymph node and tonsil: } \\
\text { Interfollicular macrophages } \\
\text { Starry sky macrophages } \\
\text { Sinus histiocytes } \\
\text { Interdigitating cells } \\
\text { Follicular dendritic cells } \\
\text { B and T cells }\end{array}$ & $\begin{array}{l}+ \\
-\star \\
+ \\
- \\
-\end{array}$ \\
\hline $\begin{array}{l}\text { Thymus: } \\
\text { Cortical and medullary macrophages } \\
\text { Cortical and medullary epithelial } \\
\text { cells } \\
\text { Thymic nurse cells } \\
\text { Cortical and medullary lymphocytes }\end{array}$ & $\begin{array}{l}+ \\
- \\
-\end{array}$ \\
\hline $\begin{array}{l}\text { Bone: } \\
\text { Osteoblasts } \\
\text { Osteoclasts }\end{array}$ & $\overline{+}$ \\
\hline $\begin{array}{l}\text { Bone marrow: } \\
\text { Granulo-monocytes } \\
\text { Erythrocytes } \\
\text { Megakaryocytes } \\
\text { Macrophages }\end{array}$ & $\begin{array}{l}- \\
\overline{-} \\
\overline{+}\end{array}$ \\
\hline $\begin{array}{l}\text { Blood: } \\
\text { All types of granulocytes } \\
\text { Monocytes } \\
\text { T lymphocytes } \\
\text { Lectin-stimulated T cells } \\
\text { B lymphocytes } \\
\text { Lectin-stimulated B cells } \\
\text { Thrombocytes } \\
\text { Erythrocytes }\end{array}$ & $\begin{array}{l}\overline{+} \text { (up to 5\%) } \\
- \\
- \\
- \\
- \\
-\end{array}$ \\
\hline $\begin{array}{l}\text { Skin: } \\
\text { Corium macrophages } \\
\text { Langerhans' cells } \\
\text { Epidermal keratinocytes }\end{array}$ & $\begin{array}{l}+ \\
- \\
-\end{array}$ \\
\hline $\begin{array}{l}\text { Macrophages of other tissues: } \\
\text { Liver (von Kupffer cells) } \\
\text { Prostate } \\
\text { Bladder } \\
\text { Kidney } \\
\text { Adrenal gland } \\
\text { Alveolar macrophages } \\
\text { Heart } \\
\text { Cardium } \\
\text { Stomach } \\
\text { Pancreas } \\
\text { Oesophagus } \\
\text { Colon } \\
\text { Jejunum } \\
\text { Testicles } \\
\text { Brain } \\
\text { Placenta }\end{array}$ & $\begin{array}{l}+ \\
+ \\
+ \\
+ \\
+ \\
+ \\
+ \\
+ \\
+ \\
+ \\
+ \\
+ \\
+ \\
+ \\
+ \\
+ \\
+\end{array}$ \\
\hline
\end{tabular}

*occasional exceptions.

†microglia cells.

nucleated giant cell macrophages of Langhans, foreign body, osteoclastic, or Touton type (figs 2E, 2G). Follicular dendritic cells (FDC) and interdigitating cells (IDC) also remained negative. The non-reactivity of Ber-MAC3 with IDC was shown on normal lymph nodes and lymph nodes displaying hyperplastic IDC (dermatophathic lymphadenopathy). The presence of IDC in these lymph node samples was confirmed by NA1/34 (CD1a) which recognises IDC and Langerhans' cells (figs 1D, 1E). Comparative stainings of adjacent sections of normal skin and oral mucosa with Ber-MAC3 and Na1/34 also showed that Ber-MAC3 did not react with Langerhans' cells.

\section{REACTIVITY OF BER-MAC3 WITH NORMAL}

HEMATOPOIETIC CELLS

Reactivity with haematopoietic cells was determined by APAAP immunostaining of smeared peripheral blood and bone marrow cell preparations, as well as by flow cytometry analysis of suspended peripheral blood cell preparations. Comparable results were obtained. Megakaryocytes, erythrocytes, and granulocytic and monocytic cells, as well as purified $T$ and $B$ cells were unreactive with the Ber-MAC3 (table 1). T cells stimulated with ConA and PHA and B cells stimulated with Staphylococcus aureus and Pokeweed mitogen were also unreactive. Only a small percentage (less than $5 \%$ ) of fresh monocytes were weakly positive with Ber-MAC3. Following isolation of monocytes by Ficoll gradient centrifugation and two hours of adherence on plastic Petri dishes, a varying percentage (5-30\%) of monocytes was weakly reactive in a granular pattern with Ber-MAC3 (fig 2A). Staining intensity and the percentage of stained monocytes steadily increased up to day 3 of culture, when $94 \%$ of monocytes were strongly positive in a granular pattern with Ber-MAC3 (fig 2B). The increase in antigen density and percentage of Ber-MAC3 positive cells were found when monocytes were cultured in normal medium, as well as in medium containing $10 \%$ human serum, LPS, or IFN-G, or when IFN-G primed monocytes were stimulated with LPS. Extended stimulation of monocytes (14 days) in the presence of human serum resulted in the formation of large cells with a macrophage-like appearance (abundant cytoplasm) as well as multinucleated giant cells. The macrophagelike cells showed a strong but diffuse cytoplasmic staining (fig 2C); giant cell macrophages were Ber-MAC3 negative. The percentage of Ber-MAC3 positive cultured monocytes determined by flow cytometry was the same for viable non-fixed and ethanol-fixed cells, but fluorescence intensity was stronger for fixed cells (table 3 ). This indicates localisation of the antigen in the cytoplasm as well as on the membrane.

\section{REACTIVITY OF BER-MAC3 WITH SOLID AND} LEUKAEMIC NEOPLASMS

Ber-MAC3 did not bind with neoplastic cells of any of the 106 various solid, nonlymphomatous lesions, or tumours (table 4). Reactive and residual mononuclear macrophages were Ber-MAC3 positive; multinucleated macrophages were Ber-MAC 3 negative (table 4).

Immunolabelling of many different lymphoid neoplasms (table 5) showed a positive reaction of the tumour cells with Ber-MAC3 in only two cases of true histiocytic malignancies,

Table 2 Reactivity of Ber-MAC3 with various types of macrophages in diseased tissue

\begin{tabular}{ll}
\hline Type of lesion/cells & $\begin{array}{l}\text { Ber-MAC3 } \\
\text { reactivity }\end{array}$ \\
\hline Sinus histiocytosis cells & + \\
Macrophages around and in necrotic lesions & + \\
$\begin{array}{l}\text { Foreign body granulomas } \\
\text { Mononucleated macrophages }\end{array}$ & + \\
Multinucleated macrophages & - \\
Touton's giant cells & - \\
Small epithelioid cell granulomas in toxoplasmosis: \\
Macrophages around the granulomas \\
Epithelioid type macrophages & + \\
Large epithelioid cell granulomas: & - \\
Macrophage around the granulomas & + \\
Epithelioid type macrophages & - \\
Langhans giant cells & - \\
\hline
\end{tabular}

*Induced by foreign body inclusions; ruptured epidermal cysts or cholesterin crystals. 
Figure 2 Ber-MAC3 staining of $(A)$ freshly prepared human monocytes, (B) monocytes cultured three days,

(C) macrophages and

giant cells differentiated from monocytes after 14 days of culture in the

presence of human serum. (D) and (E)

Immunostainings of adjacent sections of the soft tissue sarcoma showed that the S-HCL3 positive

(D) multinucleated

macrophages were

unreactive with

$\operatorname{Ber}-M A C 3$ (E).

(F) $S$-HCL3 staining of a

lymph node affected by

Piringer's lymphadenitis

and $(G) \operatorname{Ber}-M A C 3$

staining of adjacent section

shows that Ber-MAC3

reacts with neither

epithelioid type

macrophages (arrow) nor

with starry sky

macrophages.

Immunostaining of

adjacent sections of a

lymph node affected by

Hodgkin's disease with

(H) Ber-H2 (CD30) and

(I) Ber-MAC3 shows

that Ber-MAC3 reacts

with macrophages and not

with Ber-H2 positive

Hodgkin and Sternberg-

Reed cells (arrowed)
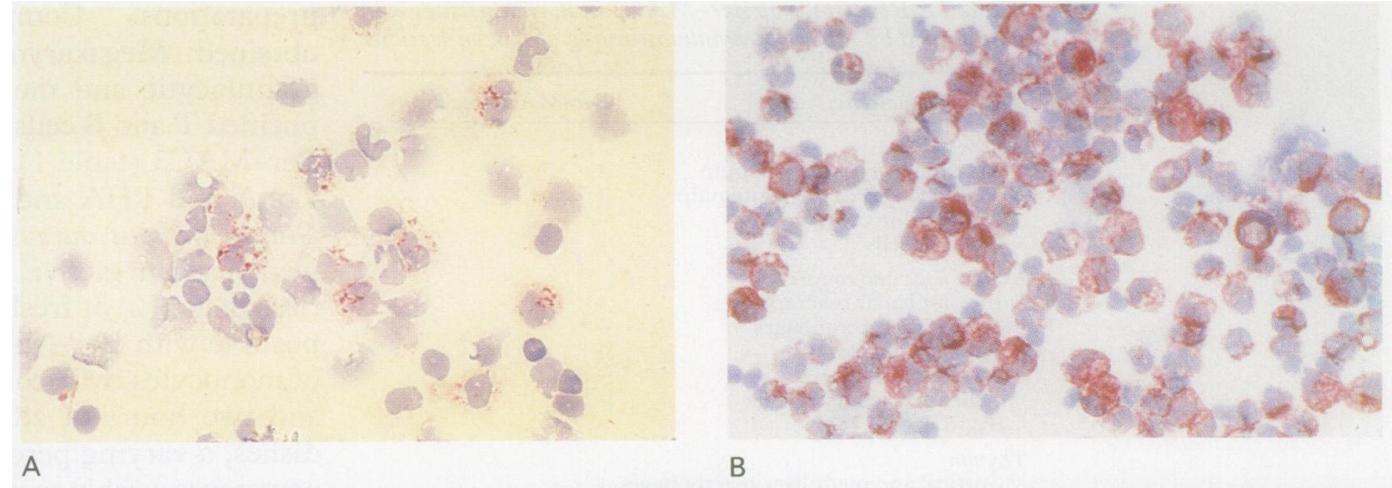

B

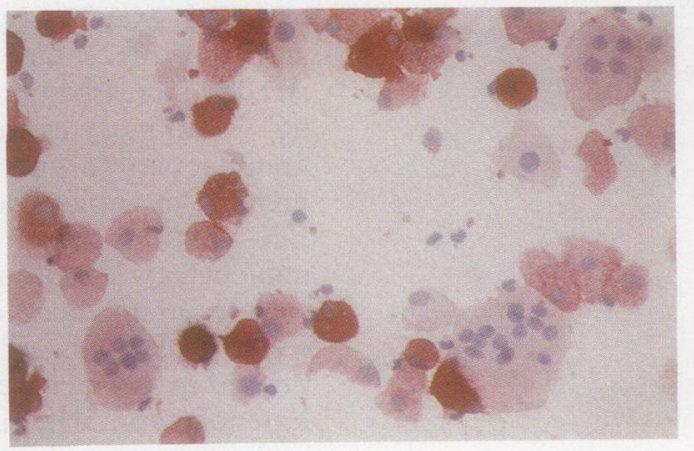

C

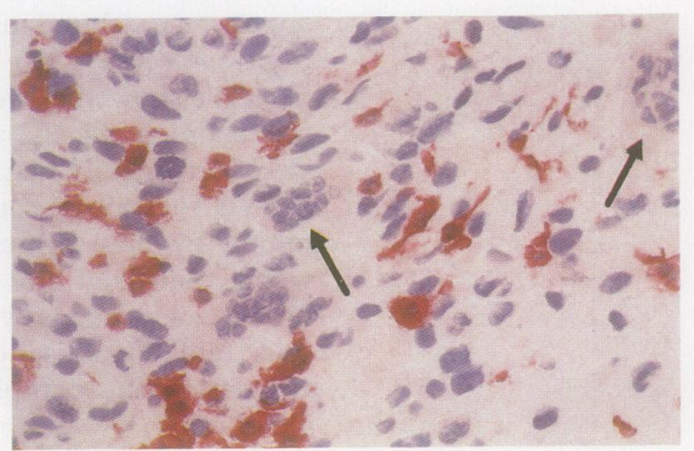

E

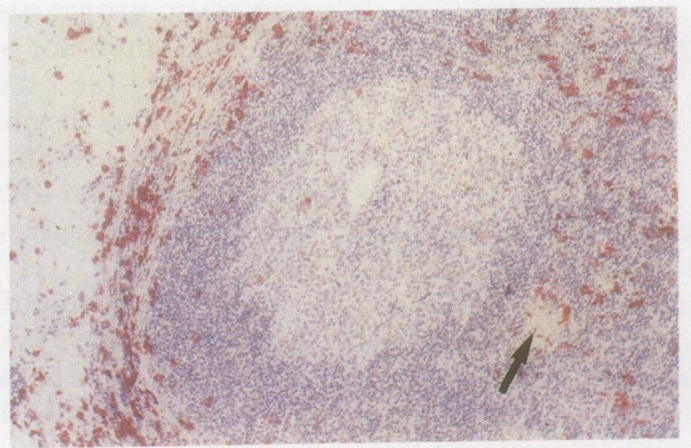

G

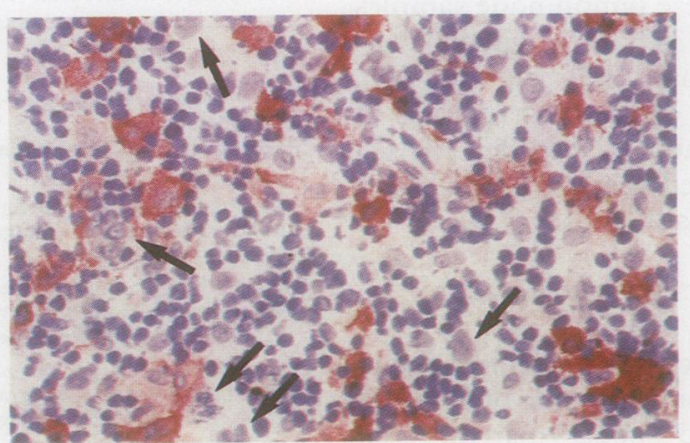


Table 3 Expression of the Ber-MAC3 on cultured human monocytes*

\begin{tabular}{|c|c|c|c|c|c|}
\hline & Day 0 & Day 1 & Day 2 & Day 3 & Day 14 \\
\hline $\begin{array}{l}\text { Viable cells: } \\
\text { Percentage of positive cells } \dagger \\
\text { Mean channel of fluorescence intensity }\end{array}$ & $\begin{array}{c}7 \\
\text { ND }\end{array}$ & $\begin{array}{l}40 \\
\text { ND }\end{array}$ & $\begin{array}{l}55 \\
48\end{array}$ & $\begin{array}{r}72 \\
125\end{array}$ & $\begin{array}{l}\text { ND } \ddagger \\
\text { ND }\end{array}$ \\
\hline $\begin{array}{l}\text { Fixed cells: } \\
\text { Percentage of positive cells } \leqslant \\
\text { Mean channel of fluorescence intensity } \\
\text { Percentage of positive cells } \dagger\end{array}$ & $\begin{array}{l}7 \\
\text { ND } \\
\leqslant 5 / 0-30 \ddagger \ddagger\end{array}$ & $\begin{array}{l}37 \\
\text { ND }\end{array}$ & $\begin{array}{r}55 \\
125 \\
81\end{array}$ & $\begin{array}{r}78 \\
137 \\
94\end{array}$ & $\begin{array}{l}\text { ND } \\
\text { ND } \\
459\end{array}$ \\
\hline
\end{tabular}

॥In percentage of the analysed cells.

Monocytes were cultured in normal medium without additives.

Motermined by flow cytometry.

†ND = not determined. expression of $\mathrm{mAb} \mathrm{Ki}-\mathrm{M} 6$, which recognises all resting monocytes.

$\$ \ddagger 5 \%$ on fresh blood monocytes; $0-30 \%$ on monocytes following Ficoll centrifugation and adherence $2 \mathrm{~h}$ on Petri dishes.

iMononuclear cells positive; multinucleated giant cells negative.

Table 4 Reactivity of Ber-MAC3 with non-lymphomatous lesions or neoplasms

\begin{tabular}{lcccc}
\hline Type of lesion/neoplasm & No of cases & $\begin{array}{l}\text { Reactive/residual } \\
\text { macrophages }\end{array}$ & $\begin{array}{l}\text { Reactive } \\
\text { multinucleated } \\
\text { macrophages }\end{array}$ & $\begin{array}{l}\text { Diseased/ } \\
\text { neoplastic cells }\end{array}$ \\
\hline $\begin{array}{l}\text { Histocytosis X } \\
\text { (Langerhans' cell histiocytosis) }\end{array}$ & 5 & + & - & - \\
$\begin{array}{l}\text { Malignant fibrous histiocytoma } \\
\text { Osteosarcoma }\end{array}$ & 7 & + & - & - \\
Rhabdo/leiomyosarcoma & 3 & + & - & - \\
Carcinoma & 15 & + & $\star$ & - \\
\hline
\end{tabular}

^Absent.

whereas the neoplastic cells of all types of the 280 malignant lymphomas were negative. The lymphomas studied included 52 cases of Hodgkin's disease and 41 cases of $\mathrm{Ki}-1$ positive anaplastic large cell lymphomas erroneously regarded as true histiocytic lymphoma. All or nearly all reactive mononuclear macrophages present in these tumours were strongly reactive with Ber-MAC3, except those present in the neoplastic follicles of follicular lymphomas. Epithelioid type macrophages occurring in lymphoepithelioid (Lennert's) lymphoma and Hodgkin's disease were Ber-MAC3-negative, as were their counterparts in reactive lesions.

The reactivity of Ber-MAC3 on myeloid leukaemias was determined by fluorescence staining of bone marrow and in some cases with the APAAP method. Ber-MAC3 reacted with only $\leqslant 5 \%$ of cells in four of the $10 \mathrm{M} 1$ leukaemias investigated (table 6), and none of the other myeloid leukaemias belonging to the
$M 1, M 2$, or $M 3$ group according to the FAB classification showed reactivity with BerMAC3. The number of Ber-MAC3 positive cells found in M4, M4/M5, and M5 leukaemias varied between $0 \%$ and $100 \%$. All cases of myeloid leukaemia showing more than $30 \%$ positive cells belonged to the monocytic M5 type.

\section{REACTIVITY OF BER-MAC3 WITH ESTABLISHED} HUMAN CELL LINES

Ber-MAC3 reacts with only $1 \%$ of cells of the HL -60 cell line, a myeloid leukaemia cell line consisting of granulocyte precursor cells (table 7); the percentage of positive cells did not change after stimulation with TPA. BerMAC3 did not react with the myeloid/erythroid leukaemia cell lines $K G-1$ and $K 562$. Although stimulation of the myeloid sarcoma cell line U937 and the monocytic leukaemia cell line THP-1 with TPA and IFN-G for 14 days

Table 5 Reactivity of Ber-MAC3 with true histiocytic malignancies and malignant lymphomas

\begin{tabular}{|c|c|c|c|}
\hline Type of lymphoma & No of cases & $\begin{array}{l}\text { Reactive/residual } \\
\text { macrophages }\end{array}$ & Tumour cells \\
\hline True histiocytic malignancy & 2 & all + & + \\
\hline $\begin{array}{l}\text { Lown grade B-NHL: } \\
\text { Diffuse } \\
\text { Follicular } \\
\text { Hairy cell leukaemia }\end{array}$ & $\begin{array}{l}45 \\
32 \\
10\end{array}$ & $\begin{array}{l}\text { all }+ \\
\text { IF }^{\star}-; E F \dagger+ \\
\text { all }+\end{array}$ & $\begin{array}{l}- \\
-\end{array}$ \\
\hline $\begin{array}{l}\text { High grade B-NHL: } \\
\text { Burkitt's lymphoma } \\
\text { Non-anaplastic large cell lymphoma } \\
\text { Ki-1 positive B-ALC lymphoma }\end{array}$ & $\begin{array}{r}3 \\
38 \\
9\end{array}$ & $\begin{array}{l}\text { all }+ \\
\text { all }+ \\
\text { all }+\end{array}$ & $\begin{array}{l}- \\
- \\
-\end{array}$ \\
\hline $\begin{array}{l}T \text {-NHL: } \\
\text { Lymphoblastic (precursor T) } \\
\text { Cutaneous T cell lymphoma } \\
\text { Pleomorphic T cell lymphoma } \\
\text { AILD-type T cell lymphoma } \\
\text { Lymphoepithelioid T cell (Lennert's) lymphoma } \\
\text { Ki-1 positive T-ALC lymphoma }\end{array}$ & $\begin{array}{r}3 \\
28 \\
18 \\
5 \\
5 \\
22\end{array}$ & $\begin{array}{l}\text { all }+ \\
\text { all }+ \\
\text { all }+ \\
\text { all }+ \\
\text { cm }+ \text {; epm }+ \text { - } \\
\text { all }+\end{array}$ & $\begin{array}{l}- \\
\overline{-} \\
\overline{-} \\
-\end{array}$ \\
\hline Ki-1 positive O-ALC lymphoma & 10 & all + & - \\
\hline Hodgkin's disease & 52 & $\operatorname{cm} t+;$ epm $t t-$ & - \\
\hline
\end{tabular}

^IF = intrafollicular macrophages identified with CD11c, CD14, and CD68.

†EF = extrafollicular macrophages.

f†epm = epithelioid type macrophages. 
Table 6 Expression of Ber-MAC3 on myeloid leukaemias

\begin{tabular}{llll}
\hline \multirow{2}{*}{$\begin{array}{l}\text { FAB } \\
\text { classification }\end{array}$} & $\begin{array}{l}\text { No of } \\
\text { cases }\end{array}$ & Reactivity: & \\
\cline { 3 - 4 } \cline { 3 - 4 } Positive cases & Positive cells \% \\
\hline M1 & 10 & $0^{\star}$ & $<5$ \\
M3 & 4 & 0 & - \\
M4 & 1 & 0 & - \\
& 6 & 3 & $<10$ \\
M5 & 9 & 3 & $<30$ \\
& & 12 & $>60$ \\
\hline
\end{tabular}

^Fewer than $5 \%$ positive leukaemic cells were found in four cases of M1 type.

Reactivity was determined by flow cytometry of bone marrow cells or by APAAP staining of cytospin preparations.

resulted in the formation of cells similar to macrophages in appearance and multinucleated giant cells, the cells were unreactive with Ber-MAC3. DHL-1, ${ }^{37}$ which is referred to as a histiocytic lymphoma cell line, was strongly positive for Ber-MAC3. No T cellderived cell lines, lymphoblastoid lines, Hodgkin's disease-derived lines, ${ }^{38-43}$ or carcinoma lines ${ }^{44}$ showed any reactivity with BerMAC3.

\section{BIOCHEMICAL CHARACTERISATION OF THE TARGET ANTIGEN}

Sodium dodecyl polyacrylamide gel electrophoresis (SDS-PAGE) of immunoprecipitates obtained with Ber-MAC3 from lysates of ${ }^{3} \mathrm{H}$ borohydride surface labelled alveolar macrophages and lysates from internally labelled $\left({ }^{35} \mathrm{~S}\right.$ methionine) DHL-1 cell line cells both showed a single glycopolypeptide chain of 140 kilodaltons under reducing conditions and 110 kilodaltons under non-reducing conditions. The 140 band and the 110 band could also be precipitated from the supernatant of the DHL1 cell line, indicating that the Ber-MAC3 molecule is released by this cell line (figs $3 A-B$ ).

\section{FUNCTIONAL ANALYSIS}

Initial investigations using varying concentrations of Ber-MAC3 ascites suggested that the Ber-MAC3 antibody has an inhibitory effect on the chemoluminescence response of monocytes. Further experiments with purified BerMAC3 antibody and Fab fragments, however, did not show any significant inhibitory effect on the generation of oxygen radicals. This indicates that the reduction of the chemoluminescence response observed with the crude ascites was not caused by Ber-MAC3 antibody, but by other constituents present in the ascites. The culturing of monocytes in the presence of Ber-MAC3 did not prevent their differentiation into macrophage-like strongly Ber-MAC3 positive cells, and afterwards into Ber-MAC3 negative multinucleated giant cell type macrophages.

\section{Discussion}

The most important features of Ber-MAC3 are as follows:

1 It recognises a single glycopolypeptide chain of 140 kilodaltons which is located in the cell membrane, and which probably contains intramolecular disulfide bridges as its molecular weight is 30000 less SDS-PAGE under nonreducing conditions.
2 It is specific for monocytes/macrophages and does not cross-react with any other cell type.

3 Presence of the Ber-MAC3 reactive antigen is related to a certain stage of monocyte/macrophage differentiation.

According to the molecular weight and binding pattern to cell lines and a wide range of tissues, Ber-MAC3 seems to be different from all reported macrophage antibodies. BerMAC3 resembled other monocyte/macrophage-specific antibodies in its strong binding to macrophages, but differed from these in its molecular weight and in its non-reactivity with granulocytes or monocytes, most starry sky macrophages, epithelioid type macrophages and multinucleated macrophages, lymphoid subpopulations, TPA-treated cells of the HL60, THP1, and U937 cell lines, follicular dendritic cells and interdigitating reticulum cells. The only monoclonal antibody that shows a tissue binding similar to that seen with Ber-MAC3 is $\mathrm{Ki}-\mathrm{M} 8$. The latter, however, differs from Ber-MAC3 in precipitating an antigen of lower molecular weight (30 and 32 kilodaltons), by its reactivity with the TPAstimulated U937 and HL60 cell line and giant cells, as well as its inhibitory effect on the generation of reactive oxidants.

Table 7 Reactivity of Ber-MAC3 with established human cell lines

\begin{tabular}{|c|c|}
\hline Cell line & Positive cells \% \\
\hline $\begin{array}{l}\text { Myeloid leukaemia cell lines: } \\
\text { KG-1 } \\
\text { K-562 } \\
\text { HL-60 } \\
\text { H1-60 IFN-G stimulated } \\
\text { HL-60 TPA stimulated }{ }^{\star}\end{array}$ & $\begin{array}{l}0 \\
0 \\
1 \\
1 \\
1\end{array}$ \\
\hline $\begin{array}{l}\text { Monocytic leukaemia cell line: } \\
\text { THP-1 } \\
\text { THP-1-IFN-G stimulated } \\
\text { THP-1 TPA stimulated } \\
\text { THP-1 LPS stimulated }\end{array}$ & $\begin{array}{l}<1 \\
<1 \\
<1 \\
<1\end{array}$ \\
\hline $\begin{array}{l}\text { Myeloid sarcoma cell line } \dagger \\
\text { U-937 } \\
\text { U-937 IFN-G stimulated } \\
\text { U-937 TPA stimulated } \\
\text { U-937 stimulated }\end{array}$ & $\begin{array}{l}0 \\
0 \\
0 \\
0\end{array}$ \\
\hline $\begin{array}{l}\text { Histiocytic cell line: } \\
\text { DHL-1 }\end{array}$ & 100 \\
\hline $\begin{array}{l}\text { Hairy cell leukaemia cell line: } \\
\text { JOK-1 }\end{array}$ & 0 \\
\hline $\begin{array}{l}\text { Hodgkin's disease derived lines: } \\
\text { L428 } \\
\text { L540 } \\
\text { L591 } \\
\text { Co. } \\
\text { KMH2 } \\
\text { Ho. }\end{array}$ & $\begin{array}{l}0 \\
0 \\
0 \\
0 \\
0 \\
0\end{array}$ \\
\hline $\begin{array}{l}\text { Lymphoblastoid cell lines: } \\
\text { CESS } \\
\text { B958 } \\
\text { BJA-B }\end{array}$ & $\begin{array}{l}0 \\
0 \\
0\end{array}$ \\
\hline $\begin{array}{l}\text { Burkitt's lymphoma derived cell } \\
\text { DAUDI } \\
\text { RAJI }\end{array}$ & $\begin{array}{l}0 \\
0\end{array}$ \\
\hline $\begin{array}{l}T \text { cell-derived cell lines: } \\
\text { MOLT4 } \\
\text { HPB-ALL } \\
\text { HUT } 102\end{array}$ & $\begin{array}{l}0 \\
0 \\
0\end{array}$ \\
\hline $\begin{array}{l}\text { Carcinoma cell lines: } \\
\text { A-431 (vulva) } \\
\text { MDA-MB-231 (breast) } \\
\text { MCF-7 (breast) } \\
\text { ALAB (breast) } \\
\text { COLO } 357 \text { (pancreas) } \\
\text { ASPC-1 (pancreas) }\end{array}$ & $\begin{array}{l}0 \\
0 \\
0 \\
0 \\
0 \\
0\end{array}$ \\
\hline
\end{tabular}

All cell lines were tested with the APAAP method.

$\star$ Expression of the p150/95 (CD11c) complex detected by $S$ HCL 3 was used as a control for the effect of TPA stimulation. tErroneously classified as histiocytic cell line. 
Figure $3 A$

Immunoprecipitation of Ber-MAC3 antigen from ${ }^{3} \mathrm{H}$ borohydride-labelled alveolar macrophages.

Immunoprecipitates were analysed by $S D S-P A G E$ using a 5\%-20\%

polyacrylamide gradient gel under reducing and

non-reducing conditions. Ber-MAC3 precipitates lanes 2 and 4; precipitates with an irrelevant

monoclonal antibody of the same subclass, lanes 1 and 3.

Figure $3 B$

Immunoprecipitation of Ber-MAC3 antigen from ${ }^{35} S$-methionine labelled DHL-1 cell line.

Molecular weight was determined by running a $10 \%$ polyacrylamide gel under reducing and nonreducing conditions, Ber-MAC3 precipitate from culture supernatant lanes 2,6 , from cell lysate lanes 4,8 . Control precipitates with an irrelevant monoclonal antibody of the same subclass lanes $1,3,5$ and

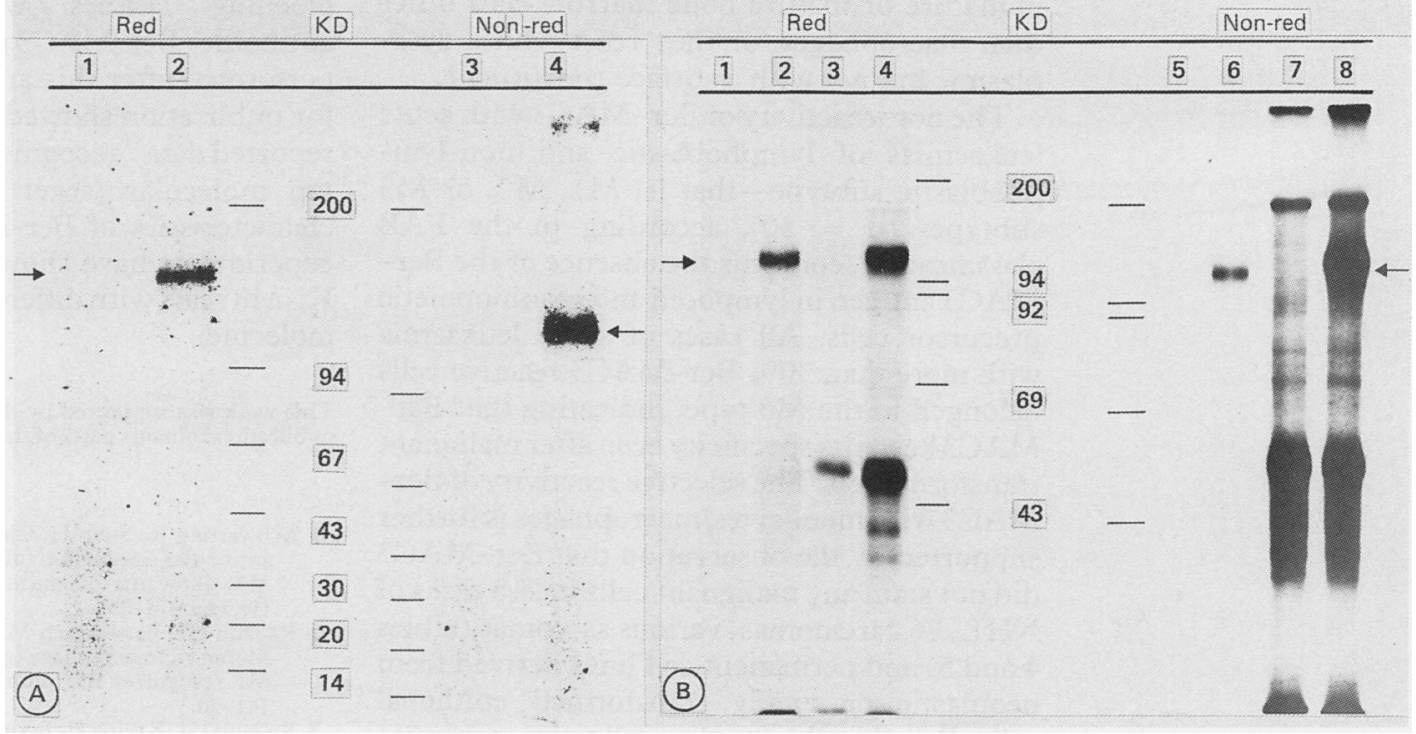

Ber-MAC3 was submitted to the 4th International Workshop and Conference on Leucocyte Differentiation Antigens in Vienna, 1989, and compared with clustered and new anti-macrophage antibodies by many different laboratories. The result of the workshop and conference studies was that Ber-MAC3 could not be assigned to any of the established or new antibody clusters. This supports the view that Ber-MAC3 recognises a new, previously undefined macrophage-associated molecule.

The most striking characteristic of BerMAC3 is its selective reactivity with monocytes and macrophages of a certain stage of differentiation. It stains weakly only a minority of nonactivated (fresh) blood monocytes, but stains very intensely monocytes stimulated by LPS, IFN-G, and/or plastic adherence, as well as tissue macrophages. If the in vitro activated monocytes are induced by prolonged culturing to differentiate further into multinucleated giant cell macrophages they become unreactive with Ber-MAC3. The same loss of Ber-MAC3 reactivity seems to take place in in vivo macrophage differentiation, as multinucleated macrophages of foreign body type, osteoclastic type, Langhans' type, etc., were not labelled by this monoclonal antibody. The differentiation of tissue macrophages into starry sky macrophages and epithelioid macrophages also proved to be associated with the loss of BerMAC3 reactivity. Interestingly, the loss of Ber-MAC3 reactivity of macrophages was also seen in certain malignant tumours if a differentiation into starry sky-like macrophages, such as follicular lymphoma, into epithelioid type macrophages (Lennert's lymphoma, certain cases of Hodgkin's disease), into osteoclastic type or other multinucleated giant cells, such as osteosarcoma, malignant fibrous histiocytoma, etc., occurs. These observations are well in line with the concept that monocytes undergo a differentiation step when they emigrate from the blood vessels and settle in the tissue as resident tissue macrophages, and that these macrophages can further transform into starry sky type, epithelioid type, or various multinucleated type macrophages at appropriate signals. The differentiation step related to emigration is associated with a steep increase of Ber-MAC3 expression. The differentiation stage defined by transformation into epithelioid type or multinucleated type macrophages is accompanied by the loss of the Ber-MAC3 molecule. In principle, this sequence of events is in keeping with other macrophage activation studies which led to the concept that monocyte/ macrophage differentiation takes place in stages. $^{4546}$

It is conceivable that for the transformation of monocytes into epithelioid type multinucleated macrophages, the expression of the Ber-MAC3 molecule or the differentiation stage associated with the strong expression of Ber-MAC3 molecule is required. If the former is true the Ber-MAC3 antigen may represent or be a part (receptor) of the signal transduction which induces the transformation into epithelioid type macrophages or fusion of single macrophages to multinucleated macrophages. This is incompatible, however, with the findings on the stimulated U937 and THP1 cell line. Stimulation of these cell lines with TPA and IFN-G leads to the expression of many monocyte/macrophage associated molecules such as CD11c, non-specific esterase, etc, ${ }^{47-49}$ and, finally, to the formation of multinucleated giant cells but not to the appearance of the Ber-MAC3 molecule. Furthermore, the Ber-MAC3 antibody did not inhibit the in vitro transformation of monocytes into multinucleated macrophages.

A further remarkable feature of $\mathrm{Ber}-$ MAC3 is its non-reactivity with cells of granulopoiesis, erythropoiesis, and megakaryopoiesis, but strong reactivity with bone marrow macrophages. This makes it a suitable tool for isolating bone marrow macrophages by positive selection or for monitoring such an attempt by negative selection. Other macrophage monoclonal antibodies are less suitable for this purpose, as they either recognise 
immature or mature bone marrow cells other than macrophages, or they react with a cytoplasmic but not with a surface constituent.

The non-reactivity of Ber-MAC3 with acute leukaemias of lymphoblastic and non-lymphoblastic subtype-that is, M1, M2, or M3 subtypes ( $\mathbf{n}=30)$, according to the FAB classification, confirms the absence of the BerMAC3 antigen in lymphoid and granulopoietic precursor cells. All cases of acute leukaemia with more than $30 \%$ Ber-MAC3 reactive cells belonged to the M5 type, indicating that BerMAC3 keeps its specificity even after malignant transformation. The selective reactivity of BerMAC3 with monocytes/macrophages is further supported by the observation that Ber-MAC3 did not stain any malignant cells in 218 cases of NHL, 76 carcinomas, various sarcomas (tables 4 and 5) and permanent cell lines derived from neoplastic or vitally transformed epithelial cells, B or T cells, or other cell types (table 7).

The tumour cells of Hodgkin's disease have been regarded as deriving from macrophages, ${ }^{5051}$ but the consistent non-reactivity of these tumour cells with Ber-MAC3 corresponds with the non-reactivity of other macrophage reagents-for example, CD11c, CD14, CD68, and lysozyme-with Sternberg-Reed cells, and thus provides further evidence against the monocyte/macrophage nature of these cells. Likewise, $\mathrm{Ki}-1$ positive anaplastic large cell lymphomas, which formerly had been regarded as true malignant histiocytic lymphomas, ${ }^{30}$ were negative with Ber-MAC3. The absence of Ber-MAC3 antigen from the tumour cells fits in with the absence of other macrophage antigens, or the presence of $T$ cell or $\mathrm{B}$ cell antigens, as well as $\mathrm{T}$ cell receptor or immunoglobulin gene rearrangement in these tumours, and thus confirms the non-histiocytic origin of $\mathrm{Ki}-1$ positive anaplastic large cell lymphomas. 5253

The only two solid neoplasms with which Ber-MAC3 gave a strongly positive reaction were the two cases of true histiocytic malignancies. This selective reactivity of Ber-MAC3 with histiocytic tumours in conjunction with its strong binding to the histiocytic lymphoma line DHL-1 shows the value of Ber-MAC3 for identifying neoplasms of true histiocytic origin.

In summary, Ber-MAC3 seems to distinguish between activated and non-activated monocytes, as well as between common tissue macrophages on the one hand, and starry sky macrophages, epithelioid type, and multinucleated type macrophages on the other hand. Ber-MAC3 is a suitable reagent for the diagnosis of myelomonocytic and monocytic leukaemias (M4/M5 subtype), as well as for the distinction of non-histiocytic neoplasms from those of true histiocytic origin. Thus BerMAC3 may be of interest for studies aimed at elucidating the regulation of differentiation of normal and neoplastic cells of the mononuclear phagocyte system and for the correlation of monocyte/macrophage functions with differentiation.

\section{Addendum}

Sequential immunoprecipitation and parallel labelling studies with the monoclonal antibodies Ber-MAC3 and $\mathrm{Ki}-\mathrm{M8}$, which were performed after this article had been accepted for publication showed that $\mathrm{Ki}-\mathrm{M} 8$, unlike the reported data, ${ }^{3}$ recognises the same 140 kilodalton molecular target and has all the other characteristics of Ber-MAC3. Cross-blocking experiments have shown that Ber-MAC3 and $\mathrm{Ki}-\mathrm{M} 8$ react with different epitopes on the same molecule.

This work was supported by the Deutsche Krebshilfe e.V. The publication contains parts of the doctoral thesis of Eva Backé.

1 Schwarting $\mathrm{R}$, Stein $\mathrm{H}$, Chang Yi Wang. The monoclonal antibodies aS-HCL1 (aLeu-14) and aS-HCL3 (aLeuM5) allow the diagnosis of hairy cell leukemia. Blood 1985;65:974-83.

2 Radzun HJ, Parwaresch MR, Feller AC, Hausmann M-L. Monocyte/macrophage-specific monoclonal antibody $\mathrm{Ki}$ M1 recognizes reticulum cells. Am J Pathol 1984;117: 441-50.

3 Radzun HJ, Kreipe H, Bödewadt S, Hausmann M-L, Barth J, Parwaresch MR. Ki-M8 monoclonal antibody reactive with an intracytoplasmatic antigen of monocyte/macrophage lineage. Blood 1987;69:1320-7.

4 Springer T, Galfre G, Secher DS, Milstein C. Mac 1: a macrophage differentiation antigen identified by monoclonal antibody. Eur J Immunol 1979;9:301-6.

5 Van Voorhis WC, Steinmann RM, Hair LS, et al. Specific antimononuclear phagocyte monoclonal antibodies. Application to the purification of dendritic cells and the tissue localization of macrophages. J Exp Med 1983; 158:126-45.

6 Hogg N, MacDonald S, Slusarenko M, Beverley PCL. Monoclonal antibodies specific for human monocytes, granulocytes and endothelium. Immunology 1984;53 753-67.

7 Zwadlo G, Bröcker EB, von Bassewitz DB, Feige U, Sorg C. A monoclonal antibody to a differentiation antigen presen on mature human macrophages and absent from monocytes. J Immunol 1984;134:1487-92.

8 Zwadlo G, Schlegel R, Sorg C. A monoclonal antibody to a subset of human monocytes found only in the peripheral blood and inflammatory tissues. J Immunol 1986;137: 512-8.

9 Breard J, Reinherz EL, Kung PC, Goldstein G, Schlossmann SF. A monoclonal antibody reactive with human mann SF. A monoclonal antibody reactive with human

10 Todd RF III, Nadler LM, Schlossmann SF. Antigens on human monocytes identified by monoclonal antibodies. $J$ Immunol 1981;126:1435-42.

11 Dimitriu-Bona A, Burmester GR, Waters SJ, Wincheste RJ. Human mononuclear phagocyte differentiation antigens. I. Patterns of antigenic expression on the surface of human monocytes and macrophages defined by monoclonal antibodies. $J$ Immunol 1983;130:145-52.

12 Seymour GJ, Poulter LH, Bofill M, et al. The reactivity of a monoclonal antibody against cells of the monocyte-macrophage series in sections of normal and inflamed human tissues. J Reticuloendothel Soc 1983;34:463-73.

13 Cuomo M, Santoro L, Mottolese M, et al. A murine monoclonal antibody strictly reactive with human perimonoclonal antibody strictly reactive with human peri1987;45:310-22.

14 Pulford KA, Rigney E, Nicklem KJ, et al. KP1; a new monoclonal antibody that detects a monocyte/macrophage associated antigen in routinely processed tissue sections. Clin Pathol 1989;42:414-21.

15 Flawell DJ, Jones DB, Wright DH. Identification of tissue histiocytes on paraffin sections by a new monoclonal antibody. J Histochem Cytochem 1987;35:1217-26.

16 Athanasou NA, Hall PA, d'Ardenne AJ, Quinn J, O'D McGee J. A monoclonal antibody (anti-L-35) which reacts with human osteoclasts and cells of the mononuclear phagocyte system. Br J Exp Pathol 1988;69:309-19.

17 Hogg N, Selvendran Y. An anti-human monocyte/macrophage monoclonal antibody reacting most strongly with macrophages in lymphoid tissue. Cell Immunol 1984; 92:247-53.

18 Munro CS, Campbell DA, Collings LA, Poulter LW Monoclonal antibodies distinguish macrophages' and Monoclonal antibodies distinguish macrophages and
epithelioid cells in sarcoidosis and leprosy. Clin Exp epithelioid cells in sarcoid

19 Bhoopat L, Turner RR, Stathopoulos E, et al. Immunohistochemical characterisation of two new monoclonal antibodies (LN-4, LN-5) reactive with human macrophage subsets and derived malignancies in B5-fixed paraffin-embedded tissues. Blood 1988;71:1079-85.

20 Hogg N, Takacs L, Palmer DG, Selvendran Y, Allen C. The p150.95 molecule is a marker of human mononuclear phagocytes: comparison with expression of class II molecules. Eur J Immunol 1986;16:240-8.

21 MacDonald SM, Pulford K, Falini B, Micklem K, Mason DY. A monoclonal antibody recognizing the p150/95 leucocyte differentiation antigen. Immunology 1986;59: 427-31. 
22 Parwaresch MR, Radzun HJ, Kreipe H, Hansmann M-L, Barth J. Monocyte/macrophage-reactive monoclonal antibody $\mathrm{Ki}-\mathrm{M} 6$ recognizes an intracytoplasmic antigen. antibody Ki-M6 recognizes an

23 Kelly PMA, Bliss E, Morton JA, Burns J, O’D McGee J. Monoclonal antibody EBM $/ 11$ : high cellular specificity for Monoclonal antibody EBM/11: high cellular specificity
human macrophages. J Clin Pathol 1988;41:510-5.

24 Davey FR, Cordell JL, Erber WN, Pulford KA, Mason DY. Monoclonal antibody (Y1/82A) with specificity towards peripheral blood monocytes and tissue macrophages. $J$ Clin Pathol 1988;41:753-8.

25 Kreipe H, Radzun HJ, Parwaresch MR. Ki-M7 monoclonal antibody specific for myelomonocytic cell lineage and macrophages in humans. $J$ Histochem Cytochem 1987; 37:1117-26.

26 Oi VT, Herzenberg LA. Immunoglobulin producing hybrid cell lines. In: Mishell BB, Shiigi SM, eds. Selected methods in cellular immunology. San Francisco: Freeman, 1980: in cellular

27 Cordell J, Falini B, Erber ON, et al. Immunoenzymatic labeling of monoclonal antibodies using immune complexes of alkaline phosphatase and monoclonal antialkaline phosphatase (APAAP Complex). J Histochem Cytochem 1984;32:219-29.

28 Tsuchiya S, Yamabe M, Yamaguchi $Y$, Kobayashi $Y$, Konno T, Tada K. Establishment and characterization of a human acute monocytic luekemia cell line (THP-1). Int J Cancer 1980;26:171-6.

29 Stein H, Gerdes J, Schwab U, et al. Evidence for the detection of the normal counterpart of Hodgkin's and Sternberg-Reed cells. Haematol Oncol 1983;1:21-9.

30 Stein $\mathrm{H}$, Mason D, Gerdes J, et al. The expression of Hodgkin's disease-associated antigen $\mathrm{Ki}-1$ in reactive and neoplastic lymphoid tissue: Evidence that Reed-Sternneoplastic lymphoid tissue: Evidence that Reed-Sternberg cells and histiocytic malignancies are derived
activated lymphoid cells. Blood 1985;66:848-58.

31 Stein H, Gerdes J, Falini B. Phenotypic and genotypic markers in malignant lymphomas: Cellular origin of Hodgkin and Sternberg-Reed cells and implications for the classification of T cell and B cell lymphomas. In: Seifert G, Hübner K. eds. Pathology of cell receptors and tumor markers. Application of immunocytochemistry and hybridization in tumor diagnosis. New York: Gustav Fischer Verlag, 1987:121.

32 Lukes R, Butler J. Histological classification of Hodgkin's disease. Cancer Res 1966;26:1063-83.

33 Naiem M, Gerdes J, Abdulaziz Z, Stein H, Mason DY. Production of a monoclonal antibody reactive with human dendritic reticulum cells and its use in the immunohisdendritic reticulum cells and its use in the immunohis-
tological analysis of lymphoid tissue. J Clin Pathol tological analysis

34 Schwarting R, Gerdes J, Stein H. Ber-H2: a new monoclonal antibody of the $\mathrm{Ki}-1$ family for the detection of Hodgkin's disease in formaldehyde-fixed tissue sections. In: McMichael AJ, ed. Leucocyte typing III. Oxford: Oxford University Press, 1987:574-5.

35 Gerdes J, Lemke H, Baisch H, Wacker HH, Schwab U, Stein H. Cell cycle analysis of a cell proliferationassociated human nuclear antigen defined by the monoclonal antibody $\mathrm{Ki}-67$. J Immunol 1984;133:1710-15.

$36 \mathrm{Gahmberg} G$, Andersson $\mathrm{L}$. Selective radioactive labeling of cell surface sialoglycoproteins by periodate-tritiated borohydride. J Biol Chem 1977;252:5888-94.

37 Hsu S-M, Hsu P-L. Phenotypes of phorbol ester-induced differentiation of human histiocytic lymphoma cell lines (U-937 and SU-DHL-1) and Reed-Sternberg cells. Am J Pathol 1986;122:133-45.

38 Kato T, Wokalek H, Schöpf E, et al. Measurement of chemoluminescence in freshly drawn human blood. Klin Wochenschr 1981;59:203-11.

39 Schaadt M, Diehl V, Stein H, Fonatsch C, Kirchner HH Two neoplastic cell lines with unique features derived from Hodkin's disease. Int J Cancer 1980;26:723-31.

40 Diehl V, Kirchner HH, Schaadt M, et al. Hodgkin's disease: Establishment of four in vitro cell lines. J Cancer Res 1981;101:111-24.

41 Diehl V, Kirchner HH, Burrichter $\mathrm{H}$, et al. Characteristics of Hodgkin's disease-derived cell lines. Cancer Treat Rep 1982;66:615-32

42 Jones DB, Scott CS, Wright DH, et al. Phenotypic analysis of an established cell line derived from a patient with Hodgkin's disease (HD). Hematol Oncol 1985;3:133-45.

43 Kamesaki H, Fukuhara S, Tatsumi E, et al. Cytochemical, immunologic, chromosomal, and molecular genetic analysis of a novel cell line derived from Hodgkin's disease. Blood 1986;68:285-92.

44 Dippold WG, Klingel R, Bernhard H, Dienes H-P, Knuth $A$, Meyer zum Büschenfelde K-H. Cell marker on gastrointestinal tumors and in human secretions defined by a monoclonal antibody. Cancer Res 1987;47:2092-7.

45 Radzun HJ.Differentiation pathway of the monocyte/macrophage system. Verh Dtsch Ges Path. 1988;72:50-6.

46 Hamilton AT, Adams DO. Molecular mechanisms of signal transduction in macrophages. Immunol Today 1987;8: 151-8.

47 Radzun HJ, Parwaresch MR, Sundström C, Nilsson K, Eissner M. Monocytic origin of the human hematopoetic
cell line U937 and its convertibility to macrophages evidenced by isoenzyme mapping. Int J Cancer 1983; evidenced

48 Ralph P, Harris PE, Punjabi CJ, et al. Lymphokine inducing 'terminal differentiation' of the human monoblast leukemia line U937: A role for y-interferon. Blood 1983;62:1169-81.

49 Tsuchiya $S$, Kobayasi $Y$, Coto $Y$, et al. Induction of maturation in cultured human monocytic leukemia cells by a phorbol-diester. Cancer Res 1982;42:1530-6.

50 Jaffe ES. Malignant histiocytosis and true histiocytic lymphomas. In: Bennington JL, ed. Surgical pathology of the lymph nodes and related organs. Philadelphia: LB Saunders, 1985:381.

51 Kaplan HS, Gartner S. Sternberg-Reed giant cells of Hodgkin's disease: Cultivation in vitro, heterotransplantation, and characterization as neoplastic macrophages. tation, and characterization as

52 Dallenbach FE, Stein H. Expression of T-cell-receptor $\beta$ chain in Reed-Sternberg cells. Lancet 1989;ii:828-30.

53 Herbst H, Tippelmann G, Anagnostopoulos I, et al. Immunoglobulin and $\mathrm{T}$-cell receptor gene rearrangements in Hodgkin's disease and $\mathrm{Ki}-1$ positive anaplastic large cell lymphoma: Dissociation between phenotype and genotype. Leuk Res 1989;13:103-16. 